ACTA MYCOLOGICA

Vol. 42 (1): 59-68

2007
Dedicated to Professor Alina Skirgietto

on the occasion of her ninety-fifth birthday

\title{
Studies on ectomycorrhizal basidiomycete in pine forest on the Lithuania-Poland transboundary region
}

\author{
DANUTE் STANKEVIČIENĖ and JONAS KASPARAVIČIUS \\ Laboratory of Mycology, Institute of Botany \\ Žaliụjų Ežerų str. 49, LT-08406 Vilnius, mikods@botanika.lt
}

\begin{abstract}
St ankevičie nè D., Kaspravičius J.: Studies on ectomycorrhizal basidiomycete in pine forest on the Lithuania-Poland transboundary region. Acta Mycol. 42 (1): 59-68, 2007.

The diversity of ectomycorrhizal fungi and sporocarps abundance were investigated in 20032005 at nine permanent study plots in a 50-year-old pine forest. Diversity of ectomycorrhizal fungi consist of 53 taxa and the majority of them belonged to the genera Cortinarius, Russula, Amanita and Tricholoma. The most frequent species, whose fruit bodies were found in each study plot, were C. cibarius, L. necator L. rufus, P. involutus, R. aeruginea, T. saponaceum and the most abundant species which made the main part of total sporocarp yield were $C$. cibarius and $P$. involutus. The lowest species richness of ectomycorrhizal fungi was in study plots with the densest cover of grasses. Maximum of species over the fruiting period was characteristic for October and for September. It was noticed that some species virtually never occurred together at the same plot (e.g. C. cibarius and $H$. aurantiaca), meanwhile others occurred together quite frequently (e.g. H. aurantiaca and X. badius).
\end{abstract}

Key words: ectomycorrhizal fungi, species richness, sporocarps abundance, pine forest

\section{INTRODUCTION}

Wild mushrooms are becoming more important as a non-timber forest product and there is a need for more site-specific data on the fungi ecology and factors that influence species diversity and production of sporocarp. Macrofungi especially ectomycorrhizal ones are organisms vitally important to the forest ecosystem. Ectomycorrhizae (EM) plays a key role in nutrient cycling and energy flow of temperate and boreal forests (S mith, Read 1997). The best known mycobionts of EM belong to the Basidiomycota. Host specificity plays an important role for the distribution of ectomycorrhizal fungi. Under natural condition wide range of ectomycorrhizal fungi develop ectomycorrhizal symbiosis with Pinus sylvestris. P. sylvestris is one of the main components of coniferous forests in Lithuania. Conifer make $58.8 \%$ of Lithuanian woodland territory, $36.4 \%$ of the territory is occupied by $P$. sylvestris and $22.4 \%$ by Picea abies ( $\mathrm{Nav}$ a a it is et al. 2003). Variations in fungal species richness, distri- 
bution, and sporocarp abundance among different forest sites have been observed and may be attributed to microclimatic and macroclimatic factors, soil properties, vegetation parameters etc. Forest age has been observed to be an important factor determining the composition of ectomycorrhizal fungi (Dighton, Mason 1985; Molina et al. 1992; Ohenoja 1993; Dahlberg et al.1997). We investigated assemblage structure of ectomycorrhizal fungi associated with 50-years-old $P$. sylvestris. The objectives of present study were: 1 ) to perform inventory of ectomycorrhizal fungus diversity, 2) to examine sporocarp abundance of ectomycorrhizal fungi aiming to determine dominant species in the investigation territory, 3) to obtain a quantitative estimate of the relative contributions of dominant ectomycorrhizal species to assemblage structure in 50-years-old P. sylvestris forest situated in LithuanianPoland transboundary region.

\section{MATERIALS AND METHODS}

Study site. The study was carried out in permanent study site, situated in Lazdijai district, southern Lithuania (125 - $135 \mathrm{~m}$ a.s.l.) (Fig. 1). The mean air temperature was $6.4^{\circ} \mathrm{C}$ and mean annual precipitation $-550 \mathrm{~mm}$. This territory is located in Lithuanian - Poland transboundary region were access for people is prohibited. This factor is important for obtaining objective investigation data because most of the ectomycorrhizal fungi are edible and intensively collected. Nine study plots $(1-9)$ were set in the 50 year-old pine forest of the Cladonio-Pinetum sylvestris Juraszek 1927 association. Area of each study plot was $900 \mathrm{~m}^{2}(30 \times 30 \mathrm{~m})$. Dominant tree species was Pinus sylvestris L. In some locations Betula pendula Roth., Quercus robur L. were intermixed. The shrub layer was predominantly by Juniperus communis L., with

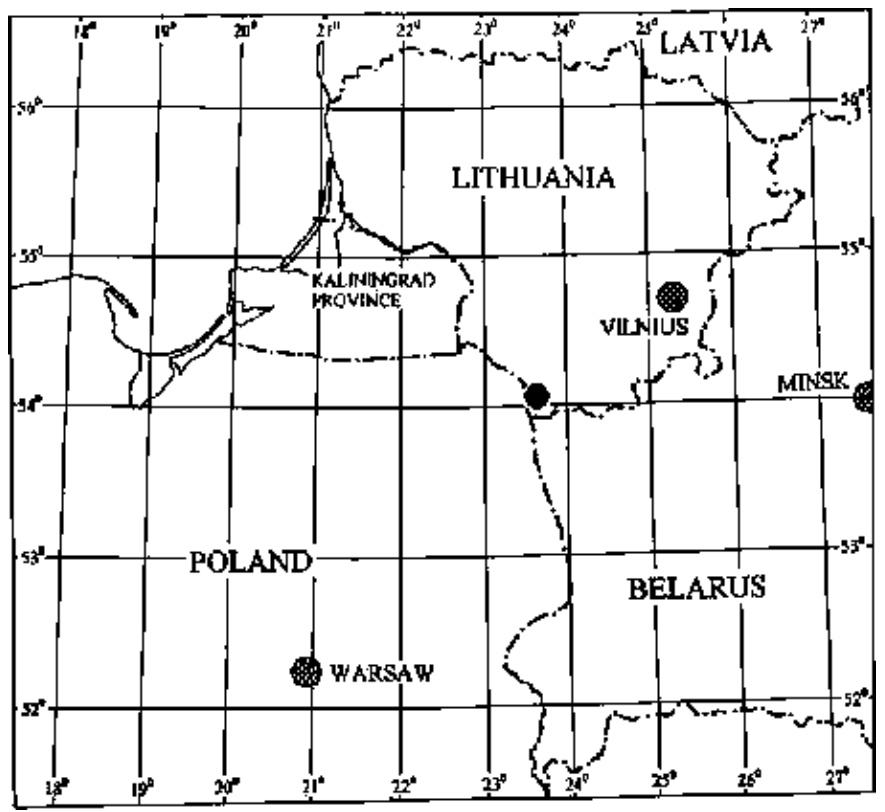

Fig. 1. Location of study area- 
Table 1

Vegetation cover (\%) of study plots (evaluation according to Braun-Blanquet method)

\begin{tabular}{|l|c|c|c|c|c|c|c|c|c|}
\hline Vegetation groups & \multicolumn{9}{|c|}{ Plots } \\
\hline & 1 & 2 & 3 & 4 & 5 & 6 & 7 & 8 & 9 \\
\hline Trees & 50 & 60 & 60 & 60 & 50 & 50 & 60 & 70 & 60 \\
\hline Shrubs & 60 & 50 & 10 & 10 & 10 & 10 & 15 & 15 & 20 \\
\hline Herbaceous plants & 50 & 30 & 10 & 10 & 10 & 10 & 20 & 20 & 40 \\
\hline Mosses, lichens & 80 & 70 & 80 & 70 & 70 & 70 & 70 & 80 & 80 \\
\hline
\end{tabular}

occasional Q. robur, Frangula alnus Mill., Sorbus aucuparia L. About $80 \%$ of study area was occupied by mosses and lichens (Tab. 1). Dominant species of mosses were Pleurozium schreberi (Brid.) Mitt., Dicranum polysetum Sw., lichens - Cladonia rangiferina (L.) Weber ex F. H. Wigg., Cladonia arbuscula (Wallr.) Flot.

Qualitative and quantitative analyses of ectomycorrhizal fungi. Species composition of fungi was inventoried at each selected forest plot every second or third week during the vegetation period in 2003 - 2005. Investigation started at the beginning of June and lasted until the first snowfall. Identification of specimens was carried out according to Moser (1983), Skirgiełło (1991, 1998), Hansen and Knudsen (1992), Urbonas $(1997,2001,2005)$ using a microscope "Jenaval Carlzeiss Jena". Voucher specimens of infrequent species found within this study are deposited in the fungal collections of the herbarium of the Institute of Botany (BILAS). Number of fruit bodies collected in each investigation plot was counted. Sporocarps were weighted and biomass of fresh sporocarps $(\mathrm{kg} / \mathrm{ha})$ was calculated.

Soil analyses. Soil samples for chemical analyses were taken with soil corer of $4.5 \mathrm{~cm}$ diameter and $6 \mathrm{~cm}$ depth in August of each investigation year. The representative sample for each research plot was prepared of 18-20 randomly taken sub-samples from each plot. These soil samples were dried and sieved before the following analyses. The concentration of nitrogen and phosphorus was determined photometrically using the photometer "SPEKOL11", of potassium - applying flame photometer "FLAPHO41", and the content of humus was ascertained colorimetrically (Min e ev 1989). Soil $\mathrm{pH}_{\mathrm{KCL}}$ was measured potentiometrically with a glass electrode in a $1.0 \mathrm{M} \mathrm{KCl}$ suspension.

Meteorological data were obtained from the State Meteorological Service.

Data analysis was carried out using the software PC-ORD4 (McCune, Mefford 1999).

\section{RESULTS AND DISCUSSION}

Chemical characteristics of soil. Chemical composition of soil directly influences functioning of fungi in the ecosystem. Therefore the concentration of main nutrient elements - N, P, K, humus and soil pH was determined. Analysing obtained data some differences were observed between study plots. The highest concentration of $\mathrm{N}, \mathrm{K}$ and humus was determined in the 9. investigation plot (Tab. 2). These concentrations were several times higher comparing to the other study plots. 9. plot is situated in the lowermost position of study area and perhaps this resulted in such a soil composition. The 8. plot distinguished by the lowest concentration of P. Higher 
Table 2

Chemical composition of soil (dw) from the study plots

\begin{tabular}{|c|c|c|c|c|c|c|}
\hline Plots & $\mathrm{N}(\%)$ & $\mathrm{P}(\%)$ & $\begin{array}{c}\mathrm{P}_{2} \mathrm{O}_{5} \\
(\mathrm{mg} / \mathrm{kg})\end{array}$ & $\mathrm{K}(\mathrm{mg} / \mathrm{kg})$ & Humus $(\%)$ & $\mathrm{pH}(\mathrm{KCL})$ \\
\hline 1 & 0,073 & 0,027 & 116,8 & 38,3 & 3,75 & 3,82 \\
\hline 2 & 0,039 & 0,035 & 150,2 & 36,1 & 3,79 & 3,76 \\
\hline 3 & 0,035 & 0,027 & 85,8 & 27,7 & 2,94 & 3,78 \\
\hline 4 & 0,029 & 0,034 & 118,4 & 21,0 & 2,71 & 3,73 \\
\hline 5 & 0,079 & 0,026 & 100,8 & 31,2 & 2,89 & 3,66 \\
\hline 6 & 0,075 & 0,029 & 107,1 & 26,1 & 2,91 & 3,69 \\
\hline 7 & 0,033 & 0,037 & 132,7 & 18,9 & 2,05 & 3,82 \\
\hline 8 & 0,058 & 0,014 & 49,4 & 29,3 & 2,97 & 3,43 \\
\hline 9 & 0,197 & 0,028 & 104,6 & 81,0 & 8,02 & 3,47 \\
\hline
\end{tabular}

concentration of this element was determined in the 2. and 7. plots. This is especially important for ectomycorrhizal fungi because concentration of nutrients alters ectomycorrhizal formation and community structure (Avis et al. 2003; S t a n k evičie né 2003; Tarvainen et al. 2003; Edwards et al. 2004; Harrington, Mitchell 2005). Other values were more or les similar comparing them between study plots.

Diversity of ectomycorrhizal fungi and sporocarp abundance. The diversity of ectomycorrhizal fungi recorded in 2003-2005 at nine permanent study plots consisted of 53 taxa (Tab. 3). Most species belonged to the genus Cortinarius -12 species $(23 \%)$ and Russula -10 (18\%). Five species were found of Amanita and Tricholoma genera, four Lactarius and three Hebeloma of. Other genera were represented by 1-2 species. Cantharellus cibarius, Lactarius necator, L. rufus, Paxillus involutus, Russula aeruginea and Tricholoma saponaceum were found in each study plot. Taylor (2002) investigating diversity of ectomycorrhizal fungi in central Sweden in a 50-year-old Pinus sylvestris stand found very similar species richness - 56 species.

Species of ectomycorrhizal basidiomycetes from the investigated pine forest could be distributed into several groups according to the abundance of formed fruit bodies. 22 species formed only small amount of fruit bodies - 10 sporocarps/investigation period. Rarest species, of which only $1-2$ fruit bodies/investigation time were found, were B. pinophilus, C. causticus, C. bovinus, C. delibutus, C. evernius, $H$. pusila, L. bicolor, L. vietus, $R$. claroflava, $R$. decolorans and T. felleus. Seven species were the most abundant and formed more than 100 fruit bodies in study plots/ investigation time. It was $C$. cibarius, $P$. involutus, Rozites caperata, L. rufus, Hygrophoropsis aurantiaca, Cortinarius mucosus and $R$. aeruginea. Those were dominant species in 50-year-old pine forest. Intermediate group was composed of 24 species which formed 11-100 fruit bodies in study area per investigation period. It is known that each forest type has its own dominant mushroom species and that dominants make main biomass of sporocarps and usually determine harvest in different forest types (Skryabina, Sennikova 1981). C. cibarius was the most abundant species, its sporocarps made about a half of the total numbers of all collected sporocarps of ectomycorrhizal fungi. $P$. involutus harvested quite abundantly also. The number of fruit bodies formed by this species made about a quarter and their biomass - about a half of the total amount of fruit bodies. Studies on fungal fruit bodies in mixed 
Table 3

Diversity of ectomycorrhizal fungi species and sporocarp abundance in study forest

\begin{tabular}{|c|c|c|c|c|c|}
\hline Species & $\begin{array}{c}\text { Species } \\
\text { code }\end{array}$ & Sum $^{1}$ & Mean $^{2}$ & Maximum $^{3}$ & $\mathrm{~S}^{4}$ \\
\hline Amanita citrina (Schaeff.) Pers. & Amcitr & 51 & 5.7 & 23 & 4 \\
\hline A. fulva (Schaeff.) Fr. & Amfulv & 26 & 2.9 & 25 & 2 \\
\hline A. muscaria (L.) Lam. & Ammusc & 53 & 5.9 & 35 & 7 \\
\hline A. porphyria Fr. & Amporf & 28 & 3.1 & 12 & 5 \\
\hline A. rubescens Pers. & Amrube & 42 & 4.7 & 15 & 7 \\
\hline Boletus edulis Bull. & Boledu & 18 & 2 & 10 & 5 \\
\hline B. pinophilus Pilát et Dermek & Bolpin & 2 & 0.2 & 1 & 2 \\
\hline Cantharellus cibarius Fr. & Cantc & 5526 & 614 & 1095 & 9 \\
\hline Cortinarius alboviolaceus (Pers.) Fr. & Cortal & 4 & 0.4 & 2 & 2 \\
\hline C. armillatus (Alb. et Schwein.) Fr. & Cortam & 11 & 1.2 & 7 & 2 \\
\hline C. causticus Fr. & Cortca & 1 & 0.1 & 1 & 1 \\
\hline C. bolaris (Pers.)Fr. & Cortbo & 3 & 0.3 & 3 & 1 \\
\hline C. bovinus Fr. & Cortbv & 1 & 0.1 & 1 & 1 \\
\hline C. cinnamomeus (L.) Fr. & Cortci & 5 & 0.6 & 3 & 2 \\
\hline C. delibutus $\mathrm{Fr}$. & Cortde & 2 & 0.2 & 2 & 1 \\
\hline C. evernius (Fr.) Fr. & Cortev & 2 & 0.2 & 2 & 1 \\
\hline C. mucosus (Bull.) Cooke & Cortmu & 146 & 16 & 45 & 8 \\
\hline C. salor $\mathrm{Fr}$. & Cortso & 3 & 0.3 & 3 & 1 \\
\hline C. semisanguineus (Fr.) Gillet & Cortse & 5 & 0.6 & 4 & 2 \\
\hline C. traganus (Fr.) Fr. & Corttr & 44 & 4.9 & 18 & 6 \\
\hline Hebeloma crustuliniforme (Bull.) Quél. & Hebecr & 44 & 4.9 & 44 & 1 \\
\hline H. longicaudum (Pers.) P. Kumm. & Hebelo & 3 & 0.3 & 3 & 1 \\
\hline H. pussilum J. E. Lange & Hebepu & 1 & 0.1 & 1 & 1 \\
\hline Hygrophoropsis aurantiaca (Wulfen) Maire & Hygaur & 173 & 19 & 65 & 7 \\
\hline Laccaria bicolor (Maire) P. D. Orton & Lacbic & 2 & 0.2 & 2 & 1 \\
\hline Lactarius necator (Bull.) Pers. & Lactne & 96 & 10.7 & 30 & 9 \\
\hline L. rufus (Scop.) Fr. & Lactru & 392 & 43.6 & 104 & 9 \\
\hline L. torminosus (Schaeff.) Gray & Lactto & 28 & 3.1 & 20 & 2 \\
\hline L. vietus (Fr.) & Lactvi & 1 & 0.1 & 1 & 1 \\
\hline Leccinum scabrum (Bull.) Gray & Leccsc & 19 & 2.1 & 7 & 8 \\
\hline Paxillus involutus (Batsch.) Fr. & Paxinv & 2475 & 275 & 552 & 9 \\
\hline Rozites caperata (Pers.) P. Karst. & Rozcap & 405 & 45 & 117 & 7 \\
\hline Russula adusta (Pers.) Fr. & Rusadu & 24 & 2.7 & 20 & 3 \\
\hline R. aeruginea $\mathrm{Fr}$. & Rusaer & 99 & 11 & 29 & 9 \\
\hline R. claroflava Grove & Ruscla & 1 & 0.1 & 1 & 1 \\
\hline R. decolorans (Fr.) Fr. & Rusdec & 2 & 0.2 & 1 & 2 \\
\hline R. emetica (Schaeff.) Pers. & Ruseme & 79 & 8.8 & 24 & 7 \\
\hline R. nigricans (Bull.) Fr. & Rusnig & 3 & 0.3 & 2 & 2 \\
\hline R. rhodopoda Zvára & Rusrod & 14 & 1.6 & 9 & 5 \\
\hline R. sanguinea (Bull.) Fr. & Russan & 3 & 0.3 & 3 & 1 \\
\hline R. vesca Fr. & Rusves & 32 & 3.6 & 13 & 8 \\
\hline R. xerampelina (Schäff. ex Secr.) Fr. & Rusxer & 4 & 0.4 & 4 & 1 \\
\hline Sarcodon imbricatus (L.) P. Karst. & Sarimb & 92 & 10.2 & 42 & 5 \\
\hline Suillus bovines (Pers.) Kuntze & Suilbo & 27 & 3 & 14 & 6 \\
\hline S. variegatus (Sw.) Kuntze & Suilva & 24 & 2.7 & 11 & 5 \\
\hline Tylopilus felleus (Bull.) P. Karst. & Tylofe & 1 & 0.1 & 1 & 1 \\
\hline Tricholoma equestre (L.) P. Kumm. & Triequ & 90 & 10 & 27 & 5 \\
\hline T. pesundatum (Fr.) Quél. & Tripes & 4 & 0.4 & 3 & 2 \\
\hline T. portentosum (Fr.) Quél & Tripo & 40 & 4.4 & 14 & 7 \\
\hline T. saponaceum (Fr.) P. Kumm. & Trisap & 78 & 8.7 & 32 & 9 \\
\hline T. sejunctum (Sowerby) Quél. & Trisej & 9 & 1 & 4 & 3 \\
\hline Xerocomus badius (Fr.) Kühner & Xerbad & 85 & 9.4 & 40 & 8 \\
\hline X. subtomentosus (Fr.) Fr. & Xersub & 34 & 3.8 & 19 & 7 \\
\hline
\end{tabular}

Explanations: ${ }^{1}$ - sum of sporocarps collected in all study plots/whole investigation period (2003-2005);

${ }^{2}-$ mean of sporocarp number yielded in one plot; ${ }^{3}$ - maximum of sporocarps yielded in one plot;

${ }^{4}$ - number of plots in which the species yielded. 
forest in Switzerland showed that abundance of ectomycorrhizal sporocarps varied over the years of the investigation and ranged from 58 to 5559 per vegetation season (Straatsma et al. 2001). Present studies showed that sporocarp abundance of ectomycorrhizal fungi in pine forest in Lithuania over the study period varied from 2487 to 5025 sporocarps per year. A total of 10808 fruit bodies of ectomycorrhizal basidiomycetes during the three year study period were collected. It made $894 \mathrm{~kg}$ (fresh weight) $/ 8100 \mathrm{~m}^{2}$ or $1104 \mathrm{~kg} / \mathrm{ha}$ per investigation time or $368 \mathrm{~kg} / \mathrm{ha}$ per one vegetation season.

According to the sporocarp abundance study plots were distributed into three groups. About 1,500 fruit bodies per investigation period were collected in the richest plots $(4,5,8)$. Plots $1-3,6$ and 9 took intermediate position and yielded $1000-1270$ fruit bodies. The least amount, a little over 300 sporocarps was found in the plot 7. It was 3-5 times lower than in the other study plots. As it was mentioned above, $C$. cibarius was the dominant species in the investigated pine forest. However, amount of fruit bodies of chanterelle in the plot 7 was very low (only 9 fruit bodies/ investigation period) and this determined the minimum total yield of sporocarps in this plot. Meanwhile $H$. aurantiaca and Xerocomus badius fruited in this plot most abundantly. It is interesting that the reliable positive correlation $(r=0.7)$ between the abundance of sporocarps of the last-mentioned species and reliable negative correlation between $C$. cibarius and $H$. aurantiaca $(\mathrm{r}=-0.70)$ also $C$. cibarius and $X$. badius $(\mathrm{r}=-0.76)$ was determined. Analysing distribution of species (these which yielded more than 5 fruit bodies per investigation period) and their frequency in study plots several groups were selected (Fig. 2). It means that is likely to find species which belong to the same group (e.g. C. cibarius, $R$. vesca, also A.porphyria, S. bovinus etc.)

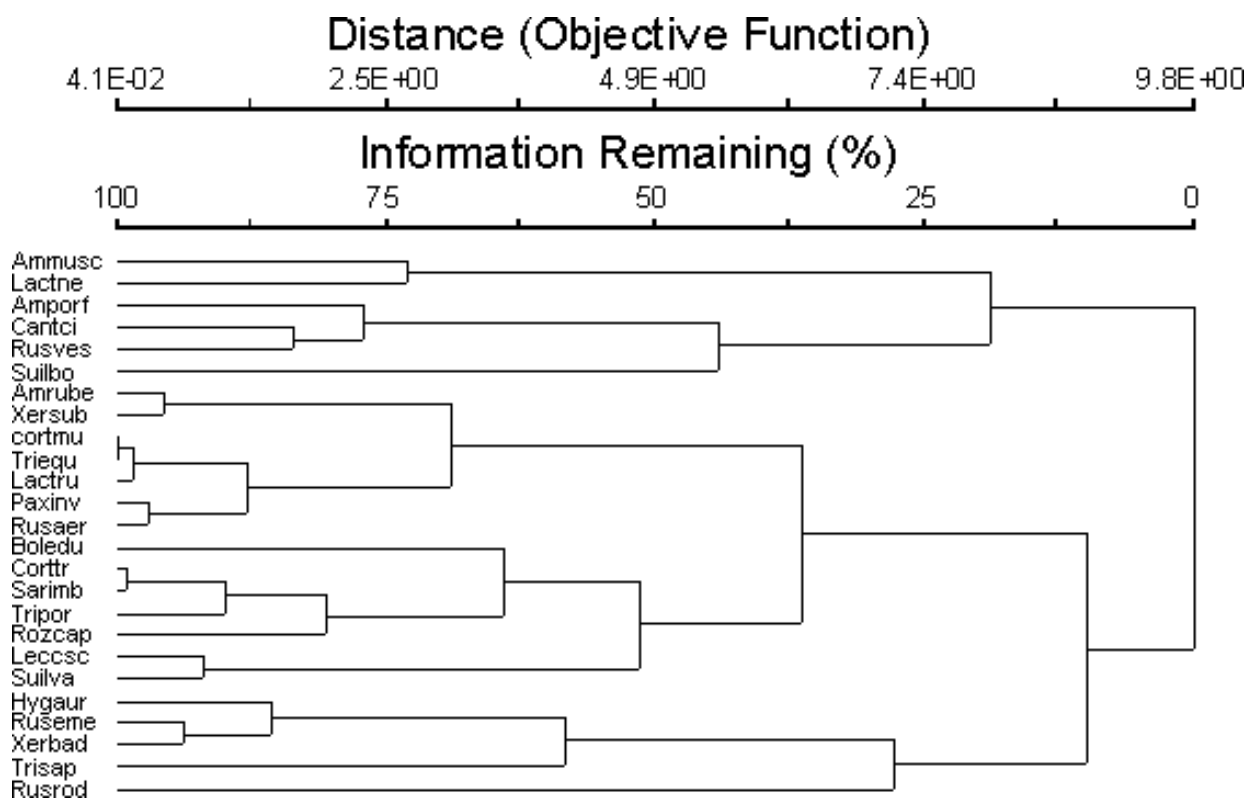

Fig. 2. Groups of ectomycorrhizal fungi species (yielded more than 5 fruit bodies per investigation time) which frequently occurred together at the same plot. 
in the same area with the similar relative abundance and on the contrary the species from different groups prefer different growing conditions. These observations were made after only three year field study. Aiming to confirm this relationship the investigation time possibly should be prolonged and at present it can be stated more as a tendency than the strong correlation. Agerer et al. (2002) while investigating correlations between ectomycorrhyzae formed by different ectomycorrhizal fungi species noted that some species show no common occurrence within shot distance, however, other indicate rather high values of common occurrence. The reasons of this phenomenon are not quite clear. The chemical composition of soil is an important factor, because varying demands of different species for soil conditions are expressed. It was determined that changes of different soil ions concentrations ( N, P, S, $\mathrm{K}, \mathrm{Na}, \mathrm{pH}$ etc.) influence above- and belowground community structure of ectomycorrhizal fungi (Tyler 1985; Agerer 1990; Erland, Söderström 1990; Fransson et al. 2000; Lilleskov et al. 2002; Agerer, Gotlein 2003, Tarvainen et al. 2003; Stankevičienè, Urbonas 2006). In the present studies the plot with the minimum amount of fruit bodies was distinguished by the lowest concentration of $\mathrm{K}$, humus and the highest value of $\mathrm{pH}$ (Tab. 2).

The lowest species richness ( 15 species) was determined in the plot 1 which characterized by the highest coverage of herbaceous plants (grasses) $(50 \%)$ and shrubs $(60 \%)$ (Tab. 1). On the other hand, the plots with the maximum species (4. plot -32 species; 9 . - 30; 3. - 29) were characterized by the lower coverage of shrubs $(10 \%)$ and grasses (10\%, except plot 9 , where coverage of grasses was $40 \%$ and shrubs -20 $\%$ ). Fungal species composition seems to be strongly determined by soil chemical properties, vegetation type, structure and age of the forest stand especially in the case of ectomycorrhizal species.

Phenology. Fruit bodies were monitored every second or third week between June and October. The start of fruiting varied strongly between the species. The longest period of fruiting was characteristic to $C$. cibarius and $P$. involutus. Fruit bodies of these species started to growth in June and fruited till the end of the vegetation season. Long fruiting period was characteristic also for L. scabrum, B. edulis, also for some species from genus Amanita, Lactarius, Russula, Xerocomus. Fruit bodies of mentioned fungi started to growth in July or August. Species from genus Cortinarius, Tricholoma, Hebeloma also Sarcodon imbricatus were found from September and their fruiting period was relatively short. Maximum species richness was characteristic for September in 2004 and for October in 2003, 2005. The dynamics curve of richness and abundance per vegetation season (June-October) was sinusoid (Fig. 3 A, B). It means that minimum value of species or sporocarps in one period (eg. a month) was compensated by the maximum in the next period and, on the contrary, the maximum was replaced by the minimum values in the following fruiting period. The dynamic of the species richness and fruit bodies abundance in 2003 and 2004 demonstrated similarities of these parameters in different fruiting periods. However, comparing appointed values between the three year period, it was noted that the curve of 2005 quite differed from 2003, 2004. The reason of these differences probably was meteorological conditions, because the curves of the dynamic of species richness, sporocarp abundance and precipitation demonstrated similar patterns in the period of $2003-2005$ (Fig. 3 A, B, C). It is known that the highest 

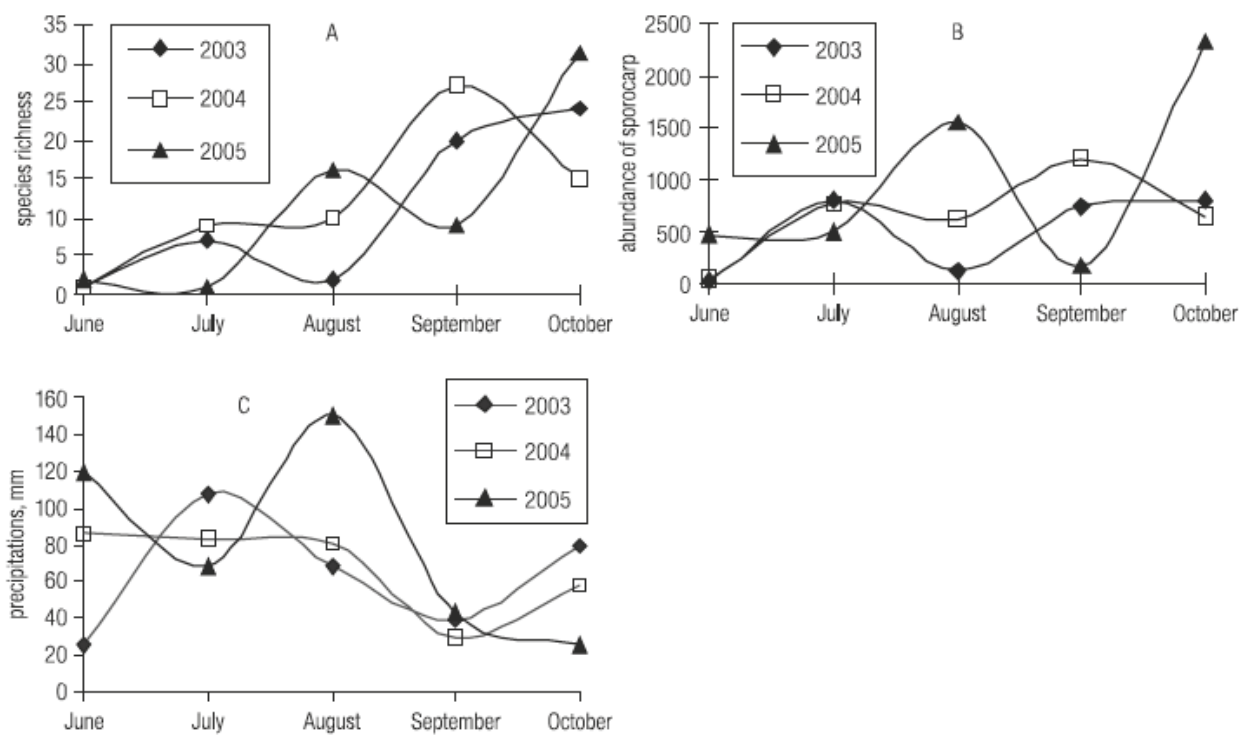

Fig. 3. Dynamics of species richness (A), sporocarp abundance (B) and precipitation (C) during vegetation period of 2003-2005.

abundance of sporocarp mainly depends on the climatic conditions (Senikova, 1984) and it is highly probable to that abundant fruiting period will supervene when the short drought period is followed by abundant precipitation (Kasparavičius, Stankevičienè 2004).

Summarizing the results of investigation it can be said that diversity of ectomycorrhizal fungi in 50-year-old pine forest consisted of 53 taxa and the majority of them belong to the genera Cortinarius, Russula, Amanita and Tricholoma. The most frequent species, which fruit bodies were found in each study plot were: $C$. cibarius, $L$. necator L. rufus, $P$. involutus, $R$. aeruginea, $T$. saponaceum and the most abundant species which made the main part of total yield of sporocarps in study forest were $C$. cibarius and $P$. involutus. The lowest species richness of ectomycorrhizal fungi showed study plots with the highest coverage of herbaceous plant and shrubs. Maximum of species over the fruiting period was characteristic for October and also for September. Sporocarp abundance was also influenced by meteorological conditions. It was noticed that some species virtually never occurred together at the same plot (e.g. C. cibarius and $H$. aurantiaca), meanwhile others occurred together quite frequently (e.g. H. aurantiaca and X. badius).

Acknowledgements: The authors are honoured by the invitation to participate in this special volume of Acta Mycologica and dedicate this paper to the distinguished friend of Lithuanian mycologists, Professor Alina Skirgiello. The investigation was supported by the Lithuanian Association of Businessmen's of Forest Mushrooms and Berries and the Lithuanian Foundation for the Science and Studies. 


\section{REFERENCES}

Agerer R. 1990. Impact of acid rain and liming on fruit body production of ectomycorrhizal fungi. Agric. Ecosyst. 28: 3-8.

Agerer R, Gotlein A. 2003. Correlations between projection area of ectomycorrhizae and $\mathrm{H}_{2} \mathrm{O}$ extractable nutrients in organic soil layers. Mycological Progress 2 (1): 45-52.

Agerer R., Grote R., Raidl S. 2002. The new method micromapping, a means to study speciesspecific associations and exclusions of ectomycorrhizae. Mycological Progress 1 (2): 155-166.

Avis P.G., Aclaughlin D.J., Dentinger B.C., Reich P.B. 2003. Long-term increase in nitrogen supply alters above- and below-ground ectomycorrhizal communities and increases the dominance of Russula spp. in a temperate oak savanna. New Phytologist 160: 239-253.

Dahlberg A., Jonsson L., Nylund J. 1997. Species diversity and distribution of biomass above and below ground among ectomycorrhizal fungi in an old-growth Norway spruce forest in south Sweden. Can. J. Bot. 75: 1323-1335.

Dight on J., Mas on P. 1985. Mycorrhizal dynamics during forest tree development. (In:) D. M o o r e, L. Casselton, D. Wood, J. Frankland (eds). Development biology in higher fungi. Cambridge University Press, Cambridge: $117-139$.

Edwards I., Cripliver J., Gillespie A., Johnsen K., Scholler M., Turco R. 2004. Nitrogen availability alters macrofungal basidiomycete community structure in optimally fertilized loblolly pine forests. New Phytol. 162: 755-770.

Erland S., Söde rs töm B. 1990. Effects of liming on ectomycorrhizal fungi infecting Pinus sylvestris L. II. Growth rates in pure culture at different $\mathrm{pH}$ values compared to growth rates in symbiosis with the host plant. New Phytol. 115: 683-688.

Fransson P.M.A., Taylor A.F.S., Finlay R.D. 2000. Effects of continuous optimal fertilization on belowground ectomycorrhizal community structure in a Norway spruce forest. Tree Physiology 20: 599-606.

Hansen L., Knudsen H. 1992. Nordic Macromycetes 2. Copenhagen.

Harrington T., Mitchell D. 2005. Ectomycorrhizas associated with a relict population of Dryas octopetala in the Burren, weatern Ireland. I. Distribution of ectomycorrhizas in relation to vegetation and soil characteristics. Mycorrhiza 15: 425-433.

Kasparavičius J., Stankevičiene D. 2004. Influance of climatic conditions (temperature and moisture) on the fruiting of Cantharellus cibarius and Boletus edulis. Biology, systematics and ecology of fungi in natural and agricultural ecosystems. Proceedings of the international scientific conference, September 20-24, 2004; Minsk: 292-297.

Lilleskov E.A., Faney T.J., Horton T.R., Lovett G.M. 2002. Belowground ectomycorrhizal fungal community change over a nitrogen deposition gradient in Alaska. Ecology 83 (1): 104-115.

McCune B., Mefford M. J. 1999. PC-ORD. Multivariate analysis of ecological data. Version 4. Oregon.

Mineev V.G. 1989. Praktikum po agrochimii. Moscow.

Molin a R., Massicotte H.B., Trappe J.M. 1992. Specificity phenomena in mycorrhizal symbioses community-ecological consequences and practical implications. (In:) M.J. Allen (ed.). Mycorrhizal functioning, an integrative plant-fungal process. Chapman and Hall, New York: 357-423.

Moser M. 1983. Die Röhrlinge und Blätterpilze (Polyporales, Boletales, Agaricales, Russulales). Fischer Verlag, Stuttgart.

Navasaitis M., Ozolinčius R., Smaliukas D., Balevičienè J. 2003. Lietuvos dendroflora (Lithuanian dendroflora). Kaunas.

Ohe noja E. 1993. Effect of weather conditions on the larger fungi at different forest site in northern Finland in 1976-1988. Acta Universitatis Ouluensis A 234: 1-69.

Se n nik ova L. S. 1984. Urozhaynost' s'edobnykh gribov v Kirovskoy oblasti. Mikologiya i fitopatologiya 18(6), 455-459.

Skirgi iełło A. 1991. Flora Polska. Grzyby (Mycota). 20. Gołąbek (Russula). PWN, Warszawa.

Skirgiełło A. 1998. Flora Ploska. Grzyby (Mycota). 25. Mleczaj (Lactarius). W. Szafer Institute of Botany, Polish Academy of Sciences, Kraków.

Skryabina A. A., Sennikova L. S. 1981. Ekologicheskiye osobennosti plodonosheniya s'edobnykh gribov v lesnykh cenozakh severo-vostoka evropeiskoy chasti SSSR. (In:) Biologicheskiye problemy Severa. Syktyvkar: 456-459. 
Smith S. E., Read D. J 1997. Mycorrhizal symbiosis. Academic, London.

Stankevičienè D. 2003. Ectomycorrhizae in a deciduous forest near a factory of chemical fertilizes. Baltic forestry 9 (1): 43-49.

Stankevičienè D., Urbonas V. 2006. Diversity of agaricoid fungi and ectomycorrhizae in deciduous forest along pollution gradient. Mycologiya i Fitopatologiya 40 (2): 108-116.

Straatsma G., Ayer F., Egli S. 2001. Species richness, abundance, and phenology of fungal fruit bodies over 21 years in a Swiss forest plot. Mycol. Res. 105 (5): 515-523.

Tarvainen O., Markkola A. M., Strommer R.2003. Diversity of macrofungi and plant in Scots pine forests along an urban pollution gradient. Basic Appl. Ecol. 4: 517-556.

Urbonas V. 1997. Baltikiečiai (Tricholomatales). Lietuvos grybai (Mycota Lithuaniae) 8 (2). Vilnius.

U rbonas V. 2001. Musmiriečiai (Amanitales), ūmèdèčiai (Russulales). Lietuvos grybai (Mycota Lithuaniae) 8 (4). Vilnius.

Urbonas V. 2005. Nuosėdiečiai (Cortinariales). Lietuvos grybai (Mycota Lithuaniae) 8 (5). Vilnius.

Taylor A. F. S. 2002. Fungal diversity in ectomycorrhizal communities: sampling effort and species detection. Plant and Soil 244: 19-28.

Tyle r G. 1985. Macrofungal flora of Swedish beech forest related to soil organic matter and acidity characteristics. Forest Ecology and Managament 10: 13-29. 